
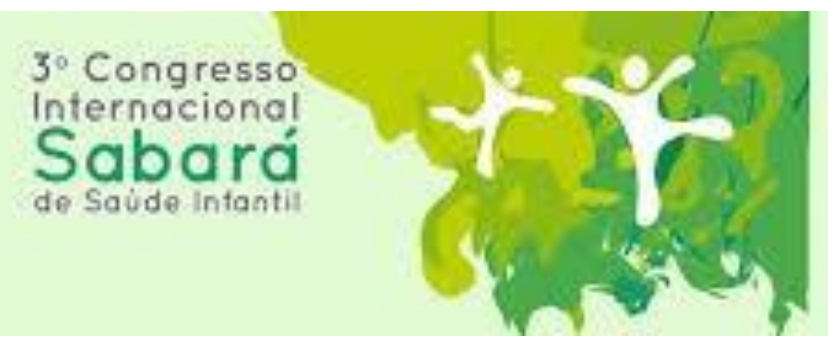

\title{
O SENTIDO DO CUIDADO A CRIANÇA HOSPITALIZADA: VIVENCIAS DE PROFISSIONAIS DE ENFERMAGEM
}

\section{Pôster}

Autores deste trabalho:

Karina Jorgino Giacomello: UNICAMP

Luciana de Lione Melo: UNICAMP

Área do Trabalho: Enfermagem pediátrica

Número de inscrição: 5371

Data da submissão:26/08/2016 às 23:03

\section{Justificativa}

O cuidado sempre esteve presente na história do ser humano como forma de garantir sua sobrevivência. Para a enfermagem, ele ocorre mediante uma situação entre uma pessoa que o fornece e outra que o recebe, de forma a promover bem-estar e conforto, com o intuito de minimizar riscos. O cuidado à criança variou da total negligência até considerála como sujeito de direitos. As primeiras hospitalizações mantinham as crianças em isolamento para prevenir a transmissão de infecções. A compreensão da família como fundamental, e do isolamento, como fator de risco emocional para a criança, surgiu na década de 1960. No Brasil, somente em 1990, com a promulgação do Estatuto da Criança e do Adolescente, as crianças passaram a ter o direito de serem acompanhadas por um responsável durante a hospitalização. Atualmente, é preconizado que o cuidado seja centrado na criança e na família, com base na assistência integral. Contudo, vários estudos evidenciam uma realidade bastante diferente.

\section{Objetivo(s)}

Compreender o sentido do cuidado à criança hospitalizada para os profissionais de enfermagem de uma unidade pediátrica.

\section{Método(s)}

Estudo fenomenológico, fundamentado na fenomenologia existencial de Martin Heidegger, realizado com dez profissionais de enfermagem que atuam em uma unidade de internação pediátrica de um hospital de ensino, no estado de São Paulo. Foram realizadas entrevistas com a questão norteadora: "O que é cuidado à criança hospitalizada para você? Conte-me, em detalhes, sua experiência em cuidar da criança hospitalizada". 


\section{Resultado(s)}

O sentido do cuidado à criança hospitalizada se dá entre o mundo da ocupação e as diversas formas de pré-ocupação. Na maioria das vezes, os profissionais permanecem envolvidos no a-gente, sendo guiados pelo falatório, decaídos enquanto seres-no-mundo. Ocupando-se/preocupando-se nos modos de ser da cotidianidade, os profissionais tendem a impropriedade, em busca da mediania e do nivelamento de todas as possibilidades de ser, porém ao extrapolar a tranquilização e o ficar preso em si mesmo atingem a empatia, o respeito e a indulgência.

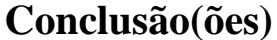

É necessário que a filosofia do cuidado à criança hospitalizada seja repensada, tanto na academia, como nas unidades de saúde, para que, de fato, seja oferecido um cuidado autêntico a essa população. 